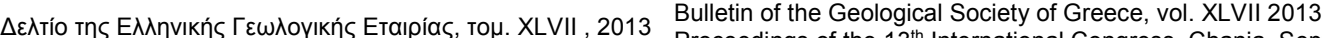

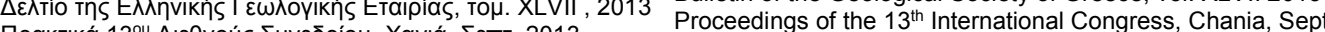

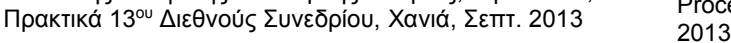

\title{
EFFECT OF WET MILLING ON THE ADSORPTION CAPACITY OF A GREEK NATURAL ZEOLITE USED FOR THE REMOVAL OF HEAVY METALS FROM SOLUTIONS
}

\author{
Katsimicha D. ${ }^{1}$, Pentari D. ${ }^{1}$, Pantelaki O. ${ }^{1}$ and Komnitsas K. ${ }^{1}$ \\ ${ }^{1}$ Technical University of Crete, Department of Mineral Resources Engineering, \\ dekatsi@yahoo.gr,pentari@mred.tuc.gr,olgapan@mred.tuc.gr,komni@mred.tuc.gr
}

\begin{abstract}
The aim of the present work is the investigation of the effect of wet milling on the adsorption capacity of a Greek natural zeolite to remove heavy metal ions from solutions. The ultimate objective is to explore the potential of producing and using fine-grained zeolite in industrial and environmental applications. For this, a rich in clinoptilolite natural zeolite, was subjected to wet milling and 3 fractions were obtained $(<10 \mu \mathrm{m}, 10-63 \mu \mathrm{m}$, and 63-200 $\mu \mathrm{m})$. The mineralogy of each fraction was determined through powder XRD and XRF analyses, while their particle size distribution and specific surface area were determined using the Laser Beam Diffraction Technique and the BET method respectively. The adsorption of $\mathrm{Cu}^{2+}, \mathrm{Ni}^{2+}, \mathrm{Mn}^{2+}$ and $\mathrm{Cd}^{2+}$ ions by each zeolite fraction was investigated using different initial metal ion concentrations (10 and $100 \mathrm{mg} / \mathrm{L}$ ) and contact times (up to $72 \mathrm{~h}$ ). The concentration of the adsorbent was kept constant $(5 \mathrm{~g} / \mathrm{L})$, whereas no $\mathrm{pH}$ adjustment took place.

The experimental results proved that wet grinding can result in the production of very fine natural zeolite $\left(d_{50}=4.37 \mu \mathrm{m}\right)$ without any loss of crystallinity and that this fraction exhibits substantial metal ion adsorption capacity. Adsorption is best described by the Freundlich isotherm.
\end{abstract}

Key words: zeolite, wet milling, adsorption, heavy metals, isotherms

\section{Пєрí $\eta \Psi \psi$}

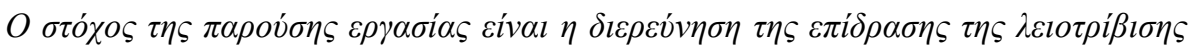

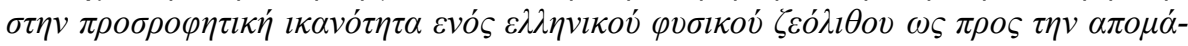

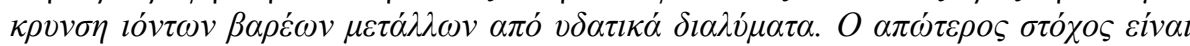

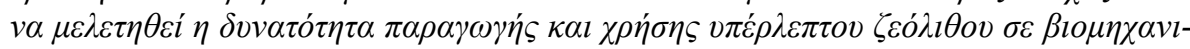

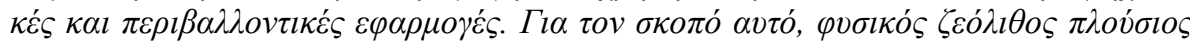

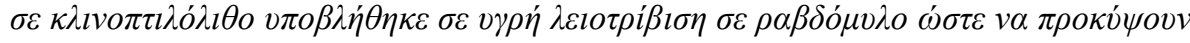

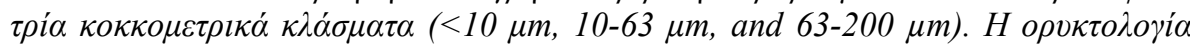

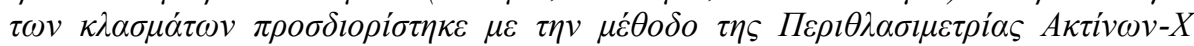

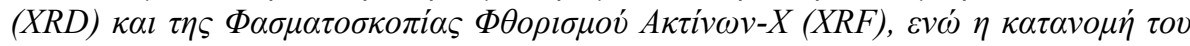

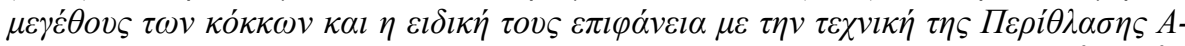

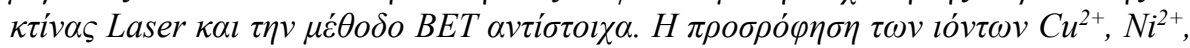

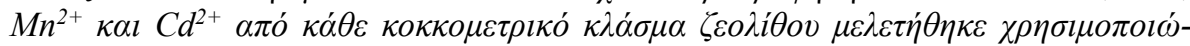

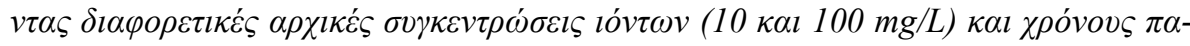

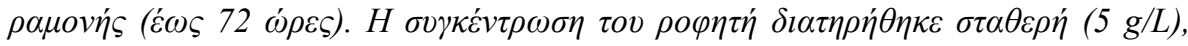

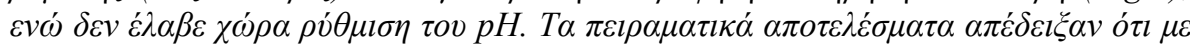

XLVII. No $2-953$ 


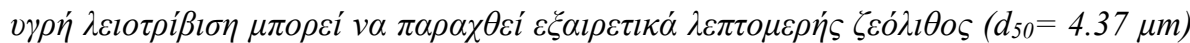

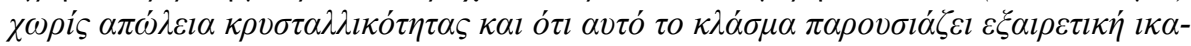

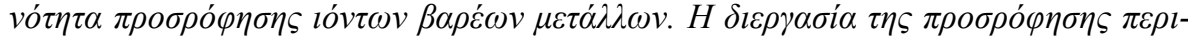

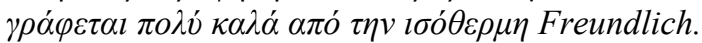

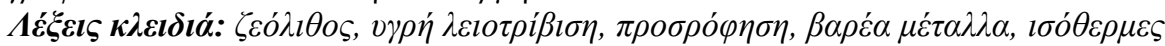

\section{Introduction}

The introduction of heavy metals to natural ecosystems has been related to many diverse human activities and is of great concern, due to the fact that these contaminants, unlike organics, are persistent in soils and non degradable, whereas if they are mobilized and released to water reservoirs may become bioavailable and threaten living organisms (Shi et al., 2009). Among several processes, such as ion-exchange, filtration, electrolytic or liquid extraction, chemical precipitation, reverse osmosis and membrane techniques (Pentari et al., 2009), adsorption can offer an easy, low-cost and effective alternative to water, wastewater and industrial effluent treatment (Wang \& Peng, 2010).

Natural zeolites are hydrated alumino-silicate minerals of a porous structure with good mechanical and thermal characteristics and beneficial physicochemical properties, like high cation exchange capacity, and potential to act as molecular sieve and catalyst (Misaelides, 2011). Their usage does not introduce additional contamination in the environment, so they can find numerous environmental and industrial applications, including uptake of heavy metals from acid mine drainage, purification of waters and industrial-urban wastewaters, management of nuclear wastes, soil remediation, drying of acid-gases, production of pozzolanic cement and lightweight aggregates, zeoponic substrates for greenhouses, deodorization products and dietary supplements for animals (Mumpton, 1999; Kulasekaran and Dendi Damodar, 2011). Natural zeolitic tuffs have been found in many countries while their world mine production in 2010 has been estimated at 2.75 million tons (USGS, 2011).

The adsorption capacity of natural and modified zeolites has been studied extensively (Panayotova \& Velikov, 2002; Caputo \& Pepe, 2007; Castaldi et al., 2008; Ghair and Ingwersen, 2009; Motsi et al., 2011). The effect of milling on the improvement of the adsorption capacity of zeolites has been also studied by several researchers (Akçay et al., 2004; Ozkan et al., 2009; Charkhi et al., 2010). Today, researchers mainly investigate the capacity of modified or non modified nano-zeolites for the adsorption of organic contaminants (Seifi et al., 2011; Hassani Nejad-Darzi et al., 2012). Future research activities will definitely focus on the adsorption capacity of modified nano-zeolites and the decontamination of industrial solutions and soils as well as on the potential hazardous impacts of zeolite nano-particles on humans and ecosystems.

The aim of the present study is the investigation of the effect of wet milling on the crystallinity and the adsorption capacity of a Greek natural zeolite used for the removal of heavy metal ions, namely $\mathrm{Cu}^{2+}, \mathrm{Ni}^{2+}, \mathrm{Mn}^{2+}$ and $\mathrm{Cd}^{2+}$, present in solutions in various concentrations. The ultimate objective is to explore the potential of using extremely fine or nano-zeolite in environmental and industrial applications.

\section{Materials and Methods}

\subsection{Zeolite Treatment}

The zeolite used in the present study originates from a natural clinoptilolite-rich deposit from the area of Petrota (Evros Prefecture, North Greece) (Filippidis et al., 2009) and its initial particle size distribution ranged between $0.3-0.8 \mathrm{~cm}$. Zeolite was subjected to wet rod milling for $20 \mathrm{~min}$ at 47 rpm using a Sepor's 5" Series Batch Rod Mill Drive. Under the optimum conditions, the mill was loaded with $9 \mathrm{~kg}$ of hardened steel rods of $23 \mathrm{~cm}$ length and varying diameter $(1.3-1.9 \mathrm{~cm}), 1 \mathrm{~L}$ water and $1 \mathrm{~kg}$ zeolite. The finely ground zeolite was then split in three fractions $(<10 \mu \mathrm{m}, 10-63$

$\underline{\text { XLVII. No } 2-954}$ 
$\mu \mathrm{m}, 63-200 \mu \mathrm{m})$ using a Richard Mozley Ltd hydro-cyclone. Finally, all fractions were dried at $100{ }^{\circ} \mathrm{C}$ for $24 \mathrm{~h}$ and then stored in plastic bags until further analysis and use.

\subsection{Characterization Studies}

The chemical analysis of all three fractions was performed through X-Ray Fluorescence, using an Energy Dispersive Spectrometer S2 RANGER Bruker apparatus. Additionally, the mineralogy of the fractions was determined through Powder X-Ray Diffraction, using a XRD D8 Advance Bruker apparatus. The data were obtained at $35 \mathrm{kV}$ and $35 \mathrm{~mA}$, with a graphite monochromator, using $\mathrm{CuK} \alpha$ radiation. The qualitative evaluation of the data was carried out with the software Diffrac Plus EVA, while the Autoquan software (based on the Rietveld method) was used for quantitative analysis.

The specific surface area of the fractions was determined using the Quantachrome Instruments Nova 2200 apparatus, according to the Brunauer, Emmett and Teller (B.E.T.) theory, while their particle size distribution through Laser Beam Diffraction, using a Mastersizer S Ver. 2.14 apparatus of MALVERN Instruments.

\subsection{Experimental Methodology}

Sorption experiments were carried out using solutions containing analytical grade nitrate salts of the corresponding metals: $\mathrm{Cu}\left(\mathrm{NO}_{3}\right)_{2} \cdot 3 \mathrm{H}_{2} \mathrm{O}, \mathrm{Ni}\left(\mathrm{NO}_{3}\right)_{2} \cdot 6 \mathrm{H}_{2} \mathrm{O}, \mathrm{Mn}\left(\mathrm{NO}_{3}\right)_{2} \cdot 4 \mathrm{H}_{2} \mathrm{O}$ and $\mathrm{Cd}\left(\mathrm{NO}_{3}\right)_{2} \cdot 4 \mathrm{H}_{2} \mathrm{O}$ (puriss p.a. quality, FLUKA). Batch experiments were performed at room temperature under continuous agitation. $0.5 \mathrm{~g}$ of air dried zeolite was added in $100 \mathrm{~mL}$ of metal solution in $200 \mathrm{~mL}$ glass beakers. Mono-component kinetic experiments were carried out for each metal ion and zeolite fraction, using two initial metal ion concentrations, namely $10 \mathrm{mg} / \mathrm{L}$ and $100 \mathrm{mg} / \mathrm{L}$. Liquid samples were withdrawn at different periods $(5 \mathrm{~min}, 15 \mathrm{~min}, 30 \mathrm{~min}, 2 \mathrm{~h}, 6 \mathrm{~h}, 18 \mathrm{~h}, 24 \mathrm{~h}, 48 \mathrm{~h}$ and $72 \mathrm{~h}$ ) and filtered to determine the residual metal ion concentration with Flame Atomic Absorption Spectroscopy, using an Analyst 100 of Perkin Elmer spectrometer. $\mathrm{pH}$ was monitored throughout the experiments using a WTW InolabLevel1 $\mathrm{pH}$ meter; no $\mathrm{pH}$ adjustment took place.

Sorption isotherms were derived only for the finest zeolite fraction $(<10 \mu \mathrm{m})$, which was proved to be the best adsorbent, by varying the initial concentration of each metal ion from 10 to $100 \mathrm{mg} / \mathrm{L}$ $(10,30,50,80$ and $100 \mathrm{mg} / \mathrm{L})$; the concentration of the adsorbent was kept constant at $5 \mathrm{~g} / \mathrm{L}$. The other conditions were kept similar to those used in kinetic studies and the retention period to reach equilibrium was maintained at $48 \mathrm{~h}$. In all tests, reagent blanks and randomly selected duplicate samples were considered for quality control/assurance and precision purposes.

\section{Results and Discussion}

\subsection{Zeolite Characteristics}

The mineralogical phases, the content in oxides, the particle size distribution and the specific surface area of each zeolite fraction are presented in Table 1 and Figure 1. As shown, the main mineralogical phases in all fractions are cliniptilolite, smectite, cristobalite, quartz and other alumino-silicates (oligoclase, illite). XRD patterns also show that the crystallinity of the fine grained zeolite is not affected by wet milling. The finer fractions are enriched in clinoptilolite and smectite whereas the content of cristobalite, quartz and oligoclase decreases to a higher or lesser extent. The $<10 \mu \mathrm{m}$ fraction contains extremely fine particles $\left(\mathrm{d}_{50}=4.37 \mu \mathrm{m}, \mathrm{d}_{10}=1.06 \mu \mathrm{m}\right)$ with a significant specific surface area $\left(18.30 \mathrm{~m}^{2} / \mathrm{g}\right), 65 \%$ larger than that of the $63-200 \mu \mathrm{m}$ fraction. 
Table 1 - Characterisation of each zeolite fraction.

\begin{tabular}{|c|c|c|c|}
\hline & $<10 \mu \mathrm{m}$ & $10-63 \mu \mathrm{m}$ & $63-200 \mu \mathrm{m}$ \\
\hline \multicolumn{4}{|l|}{ Mineralogical phases (\%) } \\
\hline Clinoptilolite & 74.91 & 75.38 & 66.61 \\
\hline Cristobalite & 4.35 & 5.60 & 6.98 \\
\hline Illite & 1.85 & 0.51 & 1.05 \\
\hline Oligoclase & 2.78 & 2.20 & 7.95 \\
\hline Quartz & 4.73 & 6.72 & 9.58 \\
\hline Smectite & 11.37 & 9.59 & 7.83 \\
\hline \multicolumn{4}{|l|}{ Oxides $(\%)$} \\
\hline $\mathrm{Na}_{2} \mathrm{O}$ & 1.31 & 1.33 & 1.17 \\
\hline $\mathrm{MgO}$ & 1.51 & 1.30 & 1.08 \\
\hline $\mathrm{K}_{2} \mathrm{O}$ & 2.97 & 3.22 & 3.20 \\
\hline $\mathrm{CaO}$ & 2.43 & 2.39 & 2.14 \\
\hline $\mathrm{TiO}_{2}$ & 0.08 & 0.11 & 0.08 \\
\hline $\mathrm{MnO}$ & 0.03 & 0.03 & 0.02 \\
\hline $\mathrm{Fe}_{2} \mathrm{O}_{3}$ & 1.56 & 1.08 & 0.84 \\
\hline $\mathrm{Al}_{2} \mathrm{O}_{3}$ & 13.58 & 12.61 & 11.82 \\
\hline $\mathrm{SiO}_{2}$ & 72.00 & 74.81 & 74.2 \\
\hline $\mathrm{P}_{2} \mathrm{O}_{5}$ & 0.00 & 0.00 & 0.00 \\
\hline L.O.I. & 9.41 & 8.71 & 7.42 \\
\hline \multicolumn{4}{|l|}{ Particle Size Distribution $(\mu \mathrm{m})$} \\
\hline $\mathrm{d}_{10}$ & 1.06 & 9.05 & 9.98 \\
\hline $\mathrm{d}_{50}$ & 4.37 & 32.66 & 92.69 \\
\hline $\mathrm{d}_{90}$ & 9.81 & 62.61 & 176.91 \\
\hline Specific Surface Area $\left(\mathrm{m}^{2} / \mathrm{g}\right)$ & 18.30 & 11.86 & 11.08 \\
\hline
\end{tabular}

\subsection{Adsorption Capacity of Zeolite}

\subsubsection{Kinetics}

The effect of retention time on the adsorption of each metal ion by each zeolite fraction is illustrated in Figure 2. In all cases the equilibrium was reached very quickly, in less than $24 \mathrm{~h}$. The experimental results show that the finest fraction $(-10 \mu \mathrm{m})$ exhibited the best adsorption capacity for all metal ions regardless of the initial concentration of $10 \mathrm{mg} / \mathrm{L}$ or $100 \mathrm{mg} / \mathrm{L}$. Metal ion removal for all elements varied between $90-96 \%$ when the initial concentration was $10 \mathrm{mg} / \mathrm{L}$; the removal percentage decreased to $67-90 \%$ when a coarser zeolite fraction $(63-200 \mu \mathrm{m})$ was used. When the initial metal ion concentration increased to $100 \mathrm{mg} / \mathrm{L}$, which is indeed high for most industrial effluents, the adsorption capacity of zeolite decreased substantially. In this case, the removal efficiency of the $-10 \mu \mathrm{m}$ fraction varied between 26 and $47 \%$. As mentioned before no $\mathrm{pH}$ adjustment was done since this was not considered necessary; $\mathrm{pH}$ in all tests varied between 5.5 and 6.5. Among the metal ions tested, zeolite exhibited its highest adsorption capacity for copper and cadmium and its lowest for nickel (Fig. 2-a,c,e for initial concentration of $10 \mathrm{mg} / \mathrm{L}$ and Fig. 2-b,d,f for initial concentration of $100 \mathrm{mg} / \mathrm{L}$ ). 
Adsorption rates for all heavy metals were much higher in the beginning of the tests but soon reached an asymptotic plateau, where the increase of retention time did not seem to be beneficial. Table 2 shows the calculated adsorption rates for all heavy metal ions when the finest zeolite fraction was used. The retention time required to reach equilibrium was $30 \mathrm{~min}$. It is observed that when the metal ion concentration was $10 \mathrm{mg} / \mathrm{L}$ adsorption rates were almost identical for $\mathrm{Cu}, \mathrm{Mn}$ and $\mathrm{Cd}(3.9 \mathrm{mg} / \mathrm{g} / \mathrm{h})$ and slightly lower for $\mathrm{Ni}(3.5 \mathrm{mg} / \mathrm{g} / \mathrm{h})$. Adsorption rates differed significantly though when the high metal ion concentration was used $(100 \mathrm{mg} / \mathrm{L})$. In this case, the highest adsorption rate was recorded for $\mathrm{Cd}(16.4 \mathrm{mg} / \mathrm{g} / \mathrm{h})$ and the lowest for $\mathrm{Ni}(9.6 \mathrm{mg} / \mathrm{g} / \mathrm{h})$. Thus, the adsorption rate sequence in decreasing order was $\mathrm{Cd}>\mathrm{Cu}>\mathrm{Mn}>\mathrm{Ni}$ and agreed with most previous studies (Erdem et al., 2004, Wang \& Peng, 2010).

The adsorption rate sequence is quite well related to the ionic radius of each heavy metal ion, which is for $\mathrm{Cd}$ : $0.95 \AA, \mathrm{Mn}: 0.83 \AA, \mathrm{Cu}: 0.73 \AA$, and Ni: $0.69 \AA$. It is shown that the higher the ionic radius the lower, in absolute values, the hydration enthalpy for all metal ions studied (Table 3 ). The enthalpy of hydration, $H_{\text {hyd }}$, in $\mathrm{kJ} / \mathrm{mole}$, of an ion is the amount of energy released when a mole of the ion dissolves in a large volume of water forming thus an infinite dilute solution. According the Eisenman-Sherry theory of cation exchange selectivity (Eisenman, 1962, Sherry, 1969), zeolites exhibit a greater preference for larger cations, like $\mathrm{Cd}^{2+}$, with greater ionic radius and lower, in absolute values, hydration enthalpy (Panayotova \& Velikov, 2002, Caputo \& Pepe, 2007).

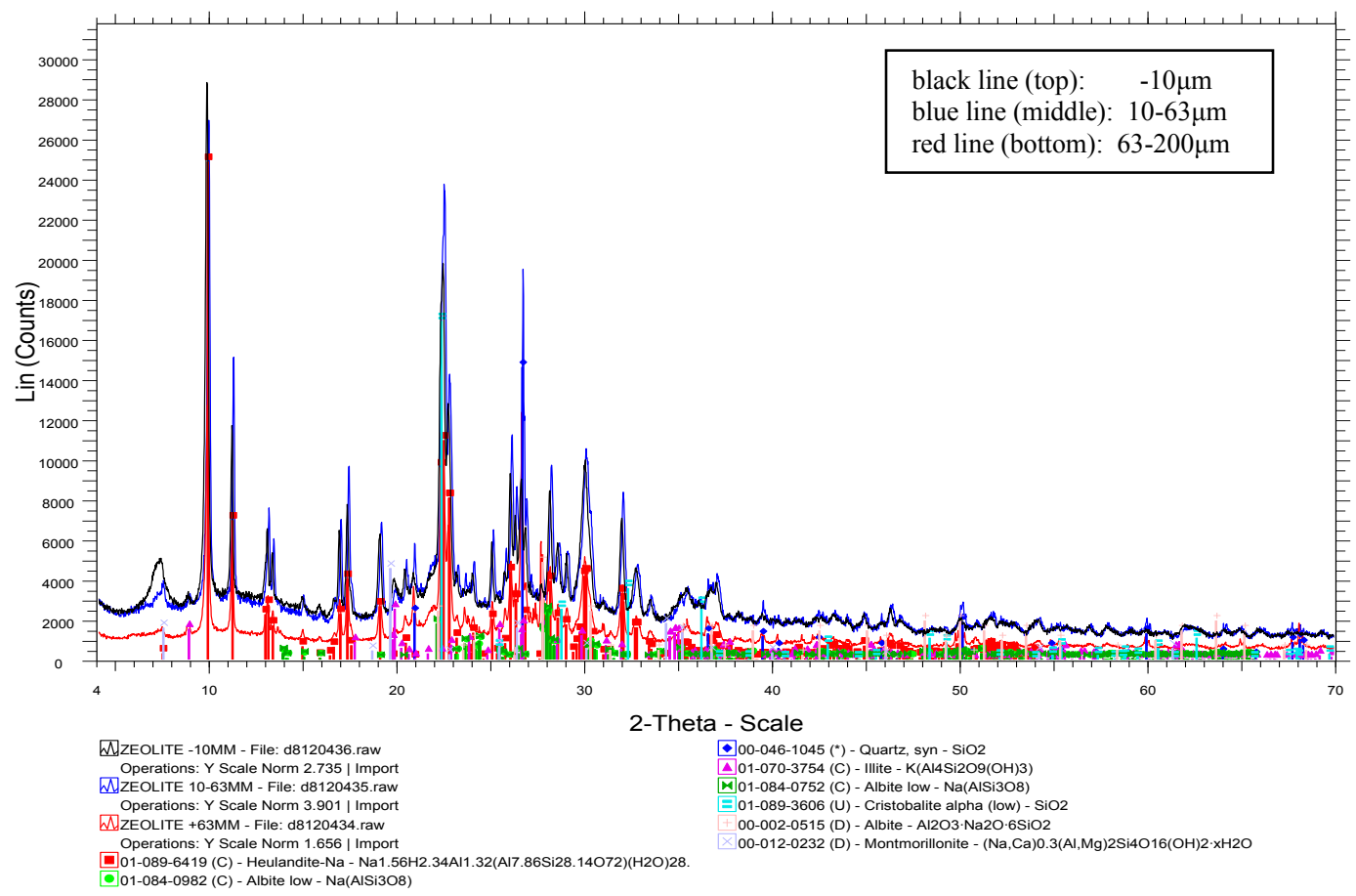

Figure 1 - XRD diffractograms of all zeolite fractions.

Table 2 - Adsorption rates (in mg metal ion/g zeolite/h) for each metal ion. Zeolite fraction $\mathbf{- 1 0} \mu \mathrm{m}$, retention time $30 \mathrm{~min}$.

\begin{tabular}{|l|r|r|r|r|}
\hline $\begin{array}{c}\text { Initial metal ion } \\
\text { concentration }\end{array}$ & \multicolumn{1}{c|}{$\mathbf{C u}$} & \multicolumn{1}{c|}{ Ni } & \multicolumn{1}{c|}{ Mn } & \multicolumn{1}{c|}{ Cd } \\
\hline $10 \mathrm{mg} / \mathrm{L}$ & 3.98 & 3.54 & 3.94 & 3.94 \\
\hline $100 \mathrm{mg} / \mathrm{L}$ & 13.70 & 9.60 & 10.40 & 16.40 \\
\hline
\end{tabular}

$\underline{\text { XLVII, No } 2-957}$ 

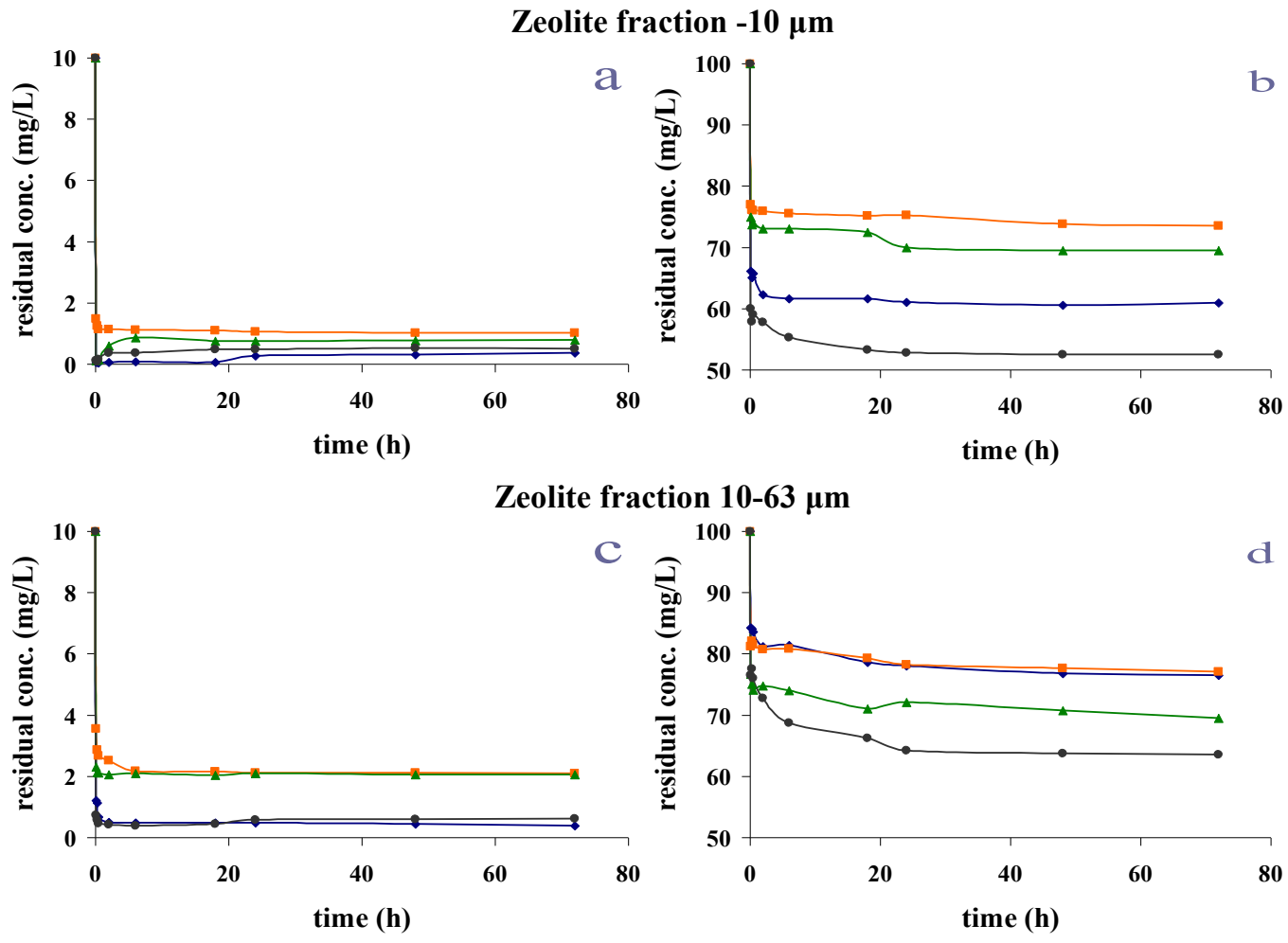

Zeolite fraction 63-200 $\mu \mathrm{m}$

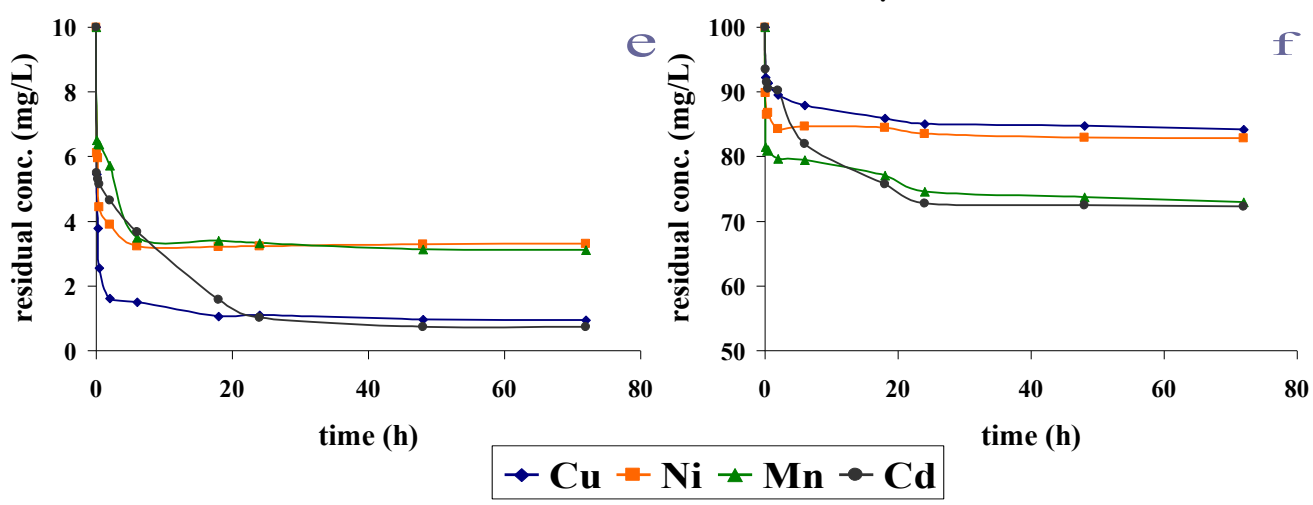

Figure 2 10 10 dsorption kinetics for each metal ion by each zeolite fraction. Experimental conditions: inftial metal ion concentration $10 \mathrm{mg} / \mathrm{L}(\mathrm{a}, \mathrm{c}, \mathrm{e})$ and $100 \mathrm{mg} / \mathrm{L}(\mathrm{b}, \mathrm{d}, \mathrm{f})$, zeolite concentration 5 gat.

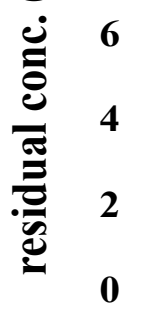

$\underline{\text { XLVII, No } 2-958}$

0 
Table 3 - Ionic radii and hydration enthalpy of the metal ions studied (Marcus, 1994).

\begin{tabular}{|l|c|c|}
\hline & $\begin{array}{c}\text { Ionic radius } \\
(\mathbf{A})\end{array}$ & $\begin{array}{c}\text { Hydration } \\
\text { enthalpy } \\
\text { (kJ/mole) }\end{array}$ \\
\hline $\mathrm{Cd}^{2+}$ & 0.95 & -1830 \\
\hline $\mathrm{Mn}^{2+}$ & 0.83 & -1870 \\
\hline $\mathrm{Cu}^{2+}$ & 0.73 & -2120 \\
\hline $\mathrm{Ni}^{2+}$ & 0.69 & -2115 \\
\hline
\end{tabular}

\subsubsection{Adsorption Isotherms}

The equilibrium data were analysed and tested against three different isotherm models, the Linear, the Freundlich and Langmuir respectively, in order to describe the adsorption of the four metal ions studied on the $-10 \mu \mathrm{m}$ zeolite fraction. The equations which were used for each model are:

\section{Equation 1 - Linear model}

$$
q_{e}=K_{P} \cdot C_{e}
$$

\section{Equation 2 - Freundlich model}

$$
q_{e}=K_{F} \cdot C_{e}^{1 / n}
$$

\section{Equation 3 - Langmuir model}

$$
\frac{q_{e}}{q_{\max }}=\frac{b \cdot C_{e}}{1+b \cdot C_{e}}
$$

where

$q_{e}(\mathrm{mg} / \mathrm{g})$, is the quantity of metal ion adsorbed per unit mass of zeolite at equilibrium,

$C_{e}(\mathrm{mg} / \mathrm{L})$, is the metal ion concentration at equilibrium,

$K_{P}(\mathrm{~L} / \mathrm{g})$, coefficient related to the affinity between the adsorbent and the ion,

$K_{F}(\mathrm{~L} / \mathrm{g})$, coefficient related to the adsorption capacity of the adsorbent

$1 / n$ (dimensionless), indicates the intensity of adsorption in relation to the heterogeneity of the adsorbent

$b(\mathrm{~L} / \mathrm{mg})$, constant related to the adsorption intensity and

$q_{\max }(\mathrm{mg} / \mathrm{g})$, is the maximum adsorption capacity of the adsorbent.

A non-linear regression analysis (Smyth, 2002) was carried out using the MATLAB R2012a software and the results are presented in Table 4.

Adsorption isotherms derived for each metal ion using the $-10 \mu \mathrm{m}$ fraction (Figure 3) indicated that are considered of "L" type according to the classification of Giles et al. (1974). This means that the concentration of a compound adsorbed on the solid mass decreases when the solute concentration increases, thus suggesting a progressive saturation of the solid (Limousin et al., 2007). 


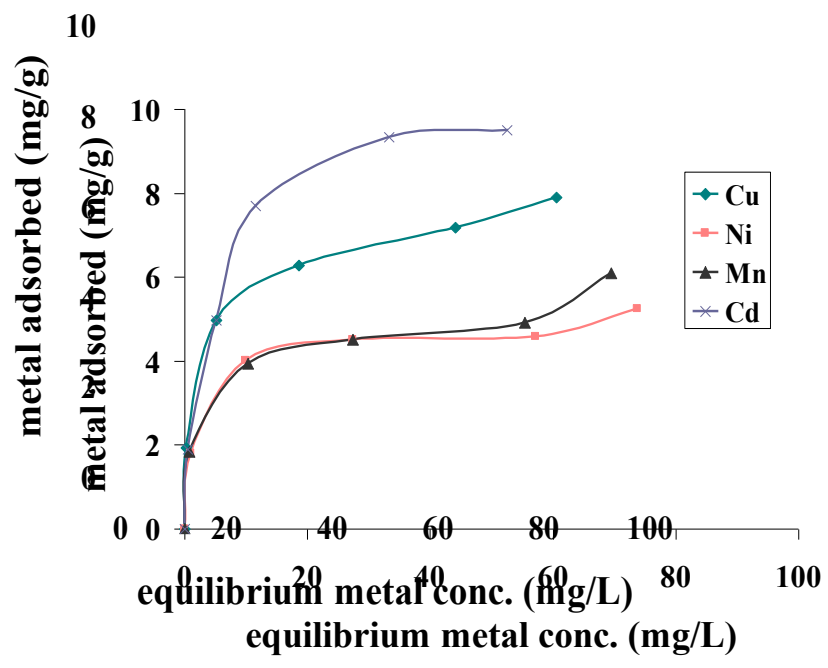

Figure 3 - Adsorption isotherms for each metal ions studied. Experimental conditions: zeolite fraction $-10 \mu \mathrm{m}$, zeolite concentration $5 \mathrm{~g} / \mathrm{L}$, metal ion concentration 10 to $100 \mathrm{mg} / \mathrm{L}$.

Table 4 - Model parameters for $\mathrm{Cu}, \mathrm{Ni}, \mathrm{Mn}$ and $\mathrm{Cd}$ adsorption by the $\mathbf{- 1 0} \boldsymbol{\mu m}$ zeolite fraction.

\begin{tabular}{|c|c|c|c|c|c|c|c|c|}
\hline \multirow{2}{*}{ Element } & \multicolumn{2}{|c|}{ Linear model } & \multicolumn{3}{c|}{ Freundlich model } & \multicolumn{3}{c|}{ Langmuir model } \\
\cline { 2 - 9 } & $\begin{array}{c}\boldsymbol{K}_{\boldsymbol{P}} \\
(\mathbf{L} / \mathbf{g})\end{array}$ & $\boldsymbol{r}^{2}$ & $\begin{array}{c}\boldsymbol{K}_{\boldsymbol{F}} \\
(\mathbf{L} / \mathbf{g})\end{array}$ & $\boldsymbol{n}$ & $\boldsymbol{r}^{2}$ & $\begin{array}{c}\boldsymbol{q}_{\max } \\
(\mathbf{m g} / \mathbf{g})\end{array}$ & $\begin{array}{c}\boldsymbol{b} \\
\mathbf{( L / m g )}\end{array}$ & $\boldsymbol{r}^{2}$ \\
\hline $\mathrm{Cu}$ & 0.157 & 0.282 & 3.140 & 4.419 & 0.990 & 7.482 & 0.510 & 0.964 \\
\hline $\mathrm{Ni}$ & 0.085 & 0.075 & 2.222 & 5.030 & 0.968 & 4.964 & 0.513 & 0.987 \\
\hline $\mathrm{Mn}$ & 0.098 & 0.363 & 2.111 & 4.261 & 0.980 & 5.307 & 0.503 & 0.940 \\
\hline $\mathrm{Cd}$ & 0.230 & 0.334 & 3.260 & 3.466 & 0.968 & 10.450 & 0.218 & 0.986 \\
\hline
\end{tabular}

As shown in Table 4 and in Figure 4, the Freundlich model fits better the experimental data; this suggests that the isotherm does not reach any plateau and consequently the studied adsorbent does not show clearly a limited adsorption capacity.

It is noted that the Langmuir isotherm describes adsorption of an ion in a single layer of an homogeneous surface of a solid particle without taking into account any interactions between the adsorbed ions or molecules. On the other hand, the Fruendlich isotherm considers an adsorbent with heterogeneous distribution of adsorption sites and takes into account potential interactions between the adsorbed ions/molecules.

It has to be mentioned that the isotherms may differ in case of simultaneous multi-component adsorption experiments. This issue is currently under investigation.

\section{Conclusions}

The experimental results show that by controlled wet rod milling of natural zeolite a well crystalline $-10 \mu \mathrm{m}$ fraction $\left(\mathrm{d}_{50}=4.37 \mu \mathrm{m}\right)$ is obtained. This fraction shows a very good adsorption capacity and can be used for the effective clean up of solutions containing up to $10 \mathrm{mg} / \mathrm{L} \mathrm{Cu}^{2+}$, $\mathrm{Ni}^{2+}, \mathrm{Mn}^{2+}$ and $\mathrm{Cd}^{2+}$ ions. Adsorption is very well described by the Freundlich model. 

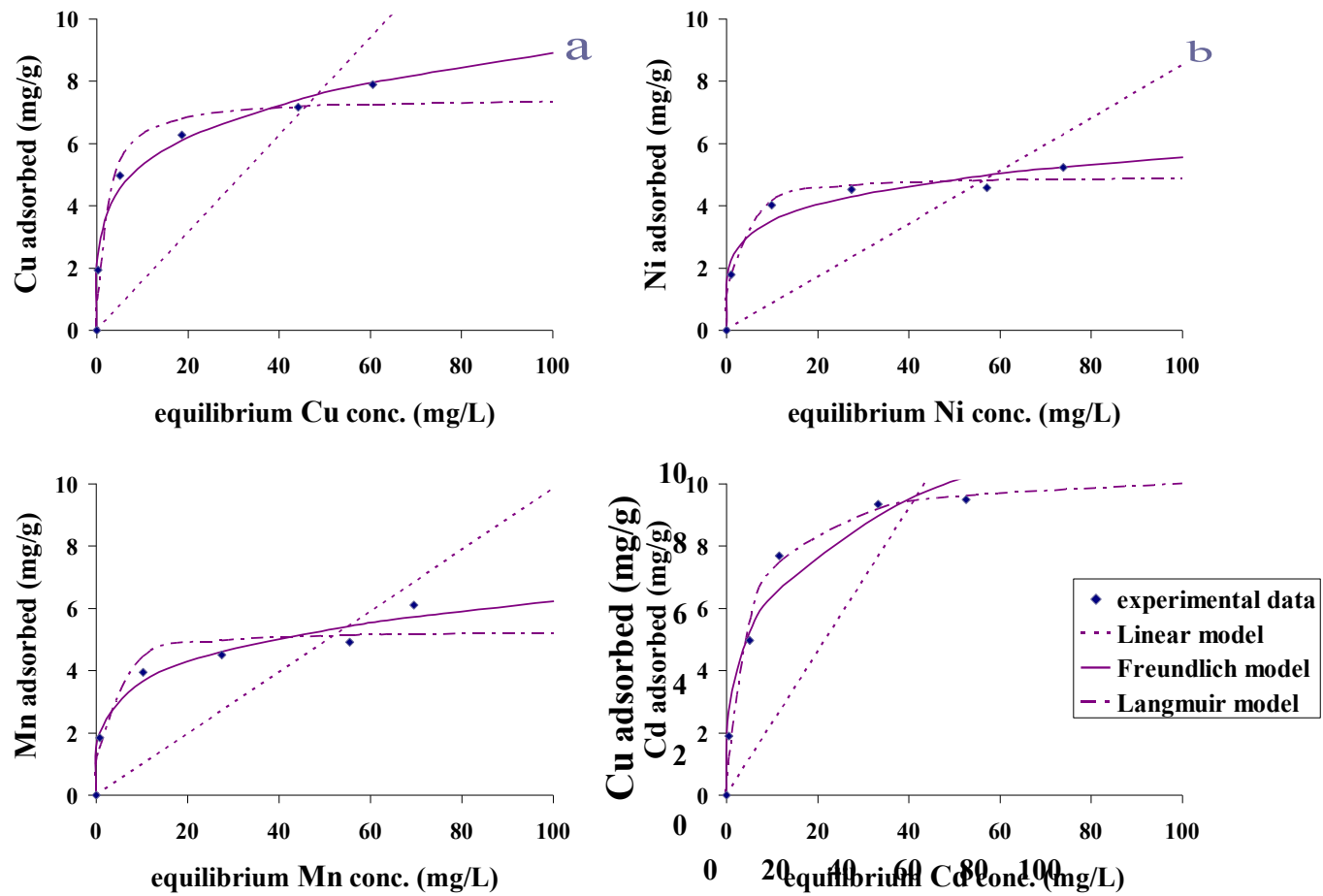

Figure 4 - Adsorption isotherms for (a) Cu, (b) Nuilibrium (c) Mn and (d) Cd. Lines represent predicted data by Linear, Freundlich and Langmuir modets while rhombus represent experimental data

\section{Acknowledgements}

This research has been co-financed by the European Union (European Social Fund - ESF) and Greek national funds through the Operational Program "Education and Lifelong Learning" of the National Strategic Reference Framework (NSRF) - Research Funding Program: THALES (Project title: Development of an integrated methodology for the management, treatment and valorisation of hazardous waste (WasteVal), proposal number:420). Prof. Komnitsas would also like to thank his colleague, Prof. Anestis Filippidis, School of Geology, Faculty of Sciences, Aristotle University of Thessaloniki, for the provision of the zeolite used in this work.

\section{References}

Akçay K., Sirkecioğlu A., Tather M., Tunç Savaşçi Ö. and Erdem-Şenatalar A. 2004. Wet ball milling of zeolite HY, Powder Technology, 142, 121-128.

Caputo D. and Pepe F. 2007. Experiments and data processing of ion exchange equilibria involving Italian natural zeolites: a review, Microporous and Mesoporous Materials, 105, 222231.

Castaldi P., Santona L., Enzo S. and Melis P. 2008. Sorption processes and XRD analysis of a natural zeolite exchanged with $\mathrm{Pb}^{2+}, \mathrm{Cd}^{2+}$ and $\mathrm{Zn}^{2+}$ cations, Journal of Hazardous Materials, $156,428-434$.

Charkhi A., Kazemian H. and Kazemeini M. 2010. Optimized experimental design for natural clinoptilolite zeolite ball milling to produce nano powders, Powder Technology, 203, 389-396.

Eisenman G. 1962. Cation selective glass electrodes and their mode of operation, Biophysical Journal, 2, 259-323. 
Erdem E., Karapinar N. and Donat R. 2004. The removal of heavy metal cations by natural zeolites, Journal of Colloid and Interface Science, 280, 309-314.

Filippidis A., Apostolidis N., Filippidis S. and Paragios I. 2009. Purification of sewage effluents and production of odorless-cohesive sewage sludge using Hellenic natural zeolite (in Greek), Hydrogaia, Honorary volume for Prof. Ch. Tzimopoulos, Faculty of Engineering, Aristotle University of Thessaloniki, 425-434.

Ghair A.M. and Ingwersen J. 2009. Nanoparticulate zeolitic tuff for immobilizing heavy metals in soil: preparation and characterization, Water, Air, and Soil Pollution, 203, 155-168.

Giles C.H., Smith D. and Huitson A. 1974. A general treatment and classification of the solute adsorption isotherm, I. Theoertical, Journal of Colloid and Interface Science, 47, 755-765.

Hassani Nejad-Darzi S.K., Samadi-Maybodi A. and Ghobakhluo M. 2013. Synthesis and characterization of modified ZSM-5 nanozeolite and their applications in adsorption of Acridine Orange dye from aqueous solution, Journal of Porous Materials, doi: 10.1007/s10934-0129668-9.

Kulasekaran R. and Dendi Damodar R. 2011. Chapter four: Zeolites and their potential uses in agriculture, Advances in Agronoly, Vol. 113, 219-241.

Limousin G., Gaudet J.P., Charlet L., Szenknect S., Bartès V. and Krimissa M. 2007. Sorption isotherms: A review on physical bases, modeling and measurement, Applied Geochemistry, $22,249-275$.

Marcus Y. 1994. A simple empirical model describing the thermodynamics of hydration of ions of widely varying charges, sizes and shapes, Biophysical Chemistry, 51 (2-3), 111-127.

Misaelides P. 2011. Application of natural zeolites in environmental remediation: A short review, Microporous and Mesoporous Materials, 144, 15-18.

Motsi T., Rowson N.A. and Simmons M.J.H. 2011. Kinetic studies of the removal of heavy metals from acid mine drainage by natural zeolite, International Journal of Mineral Processing, $101,42-49$.

Mumpton F.A. 1999. La roca magica: Uses of natural zeolites in agriculture and industry, Proceedings of the National Academy of Sciences USA, Vol. 96, 3463-3470.

Ozkan A., Yekeler M. and Calkaya M. 2009. Kinetics of fine wet grinding of zeolite in a steel ball mill in comparison to dry grinding, International Journal of Mineral Processing, 90, 67-73.

Panayotova M. and Velikov B. 2002. Kinetics of heavy metal ions removal by use of natural zeolite, Journal of Environmental Science and Health, A37(2), 139-147.

Pentari D., Perdikatsis V., Katsimicha D. and Kanaki A. 2009. Sorption properties of low calorific value greek lignites: removal of lead, cadmium, zinc and copper ions from aqueous solutions, Journal of Hazardous Materials, 168, 1017-1021.

Seifi L., Torabian A., Kazemian H., Bidhendi G.N., Azimi A.A. and Charkhi A. 2011. Adsorption of petroleum monoaromatics from aqueous solutions using granulated surface modified natural nanozeolites: Systematic study of equilibrium isotherms, Water, Air, and Soil Pollution, 217(1-4), 611-625.

Sherry H.S. 1969. The ion-exchange properties of the zeolites, In: Marinsky J.A. ed., Ion Exchange: A Series of Advances, Vol.2, Marcel Dekker, New York, 89-133.

Shi W.-Y., Shao H.B., Li H., Shao M.A. and Du S., 2009. Progress in the remediation of hazardous heavy-metal polluted soils by natural zaolite, Journal of Hazardous Materials, 170, 16.

Smyth G.K. 2002. Nonlinear regression, In: El-Shaarawi A.H. and Piegorsch W.W. eds., Encyclopedia of Environmetrics, Vol.3, 1405-1411, Wiley, J. \& Sons, Ltd, Chichester.

USGS 2011. Zeolites (Natural), U.S. Geological Survey, Mineral Commodity Summaries, January 2011.

Wang S. and Peng Y. 2010. Natural zeolites as effective adsorbents in water and wastewater treatment, Chemical Engineering Journal, 156, 11-24. 